\title{
Phytotoxicity and Benzoxazinone Concentration in Field Grown Cereal Rye (Secale cereale $\mathbf{L}_{\text {.) }}$
}

\author{
C. La Hovary, ${ }^{1}$ D. A. Danehower, ${ }^{2}$ G. Ma, ${ }^{3}$ C. Reberg-Horton, ${ }^{4}$ \\ J. D. Williamson, ${ }^{3}$ S. R. Baerson, ${ }^{5}$ and J. D. Burton ${ }^{3}$ \\ ${ }^{1}$ Department of Plant and Microbial Biology, North Carolina State University, Raleigh, NC 27695, USA \\ ${ }^{2}$ Avoca, Inc., P.O. Box 129, 841 Avoca Farm Road, Merry Hill, NC 27957, USA \\ ${ }^{3}$ Department of Horticultural Science, North Carolina State University, Raleigh, NC 27695, USA \\ ${ }^{4}$ Department of Crop Science, North Carolina State University, Raleigh, NC 27695, USA \\ ${ }^{5}$ USDA-ARS, Natural Products Utilization Research Unit, University, MS 38677, USA
}

Correspondence should be addressed to J. D. Burton; jim_burton@ncsu.edu

Received 5 October 2015; Revised 8 December 2015; Accepted 10 December 2015

Academic Editor: Othmane Merah

Copyright (C) 2016 C. La Hovary et al. This is an open access article distributed under the Creative Commons Attribution License, which permits unrestricted use, distribution, and reproduction in any medium, provided the original work is properly cited.

\begin{abstract}
Winter rye (Secale cereale L.) is used as a cover crop because of the weed suppression potential of its mulch. To gain insight into the more effective use of rye as a cover crop we assessed changes in benzoxazinone (BX) levels in rye shoot tissue over the growing season. Four rye varieties were planted in the fall and samples harvested at intervals the following spring. Two different measures of phytotoxic compound content were taken. Seed germination bioassays were used as an estimate of total phytotoxic potential. Dilutions of shoot extracts were tested using two indicator species to compare the relative toxicity of tissue. In addition, BX (DIBOA, DIBOA-glycoside, and BOA) levels were directly determined using gas chromatography. Results showed that rye tissue harvested in March was the most toxic to indicator species, with toxicity decreasing thereafter. Likewise the BX concentration in rye shoot tissue increased early in the season and then decreased over time. Thus, phytotoxicity measured by bioassay and BX levels measured by GC have a similar but not identical temporal profile. The observed decrease in phytotoxic potential and plant BX levels in rye later in the season appears to correlate with the transition from vegetative to reproductive growth.
\end{abstract}

\section{Introduction}

The agricultural use of cover crops has many potential benefits including reduced soil erosion, decreased nutrient runoff, increased soil organic matter, improved soil tilth, the ability to scavenge residual nitrogen, and the suppression of weed growth $[1,2]$. Suppression of weed growth is of particular importance to organic growers, due to restrictions in herbicide use $[3,4]$. In general, cover crops suppress weed growth by both physical competition and chemical interference. Chemical interference involves the production and release of allelopathic chemicals, primary and secondary metabolites that are phytotoxic or have growth regulating properties. Allelopathy refers to a broad range of biochemical interactions between organisms [5-8]. Many examples of allelopathic chemicals from plants have been described, including sorgoleone from Sorghum Moench spp. [9], juglone from walnut [10], artemisinin from Artemisia L. spp. [6], and the benzoxazinones (BXs) and their metabolites from corn, wheat, and rye [11-15].

Cereal rye (Secale cereale L.) is widely used as a winter cover crop because of its winter hardiness, high biomass productivity, low cost, and effectiveness in controlling weeds in multiple crops that are planted into the killed cover crop in the spring [16-19]. Several allelopathic chemicals have been identified in rye foliage, including the benzoxazinones (BXs), or cyclic hydroxamic acids, such as DIBOA (2,4-dihydroxy$2 H$-1,4-benzoxazin-3(4H)-one) $[20,21]$ and its metabolites, and organic acids ( $\beta$-phenyllactic acid and $\beta$-hydroxybutyric acid) $[21,22]$. DIBOA and other BXs have been the focus of extensive research because they have broad biological activity, including antibacterial, antifungal, and antifeedant properties $[8,21,23]$. Further emphasizing the versatility of this chemistry, BXs have also been under investigation for 
use as pharmaceuticals [24-27]. DIBOA and its metabolites are major allelochemicals in rye, as is demonstrated by their inhibition of seedling growth in bioassays [28, 29]. Additional evidence for the activity of BXs in vivo was provided by studies with wheat, where they accounted for $69 \%$ of the variation in root exudate phytotoxicity [30]. Analysis of the decomposition of rye shoot tissue in soil produced a complex BX profile over time [31], and microbiological studies have demonstrated that BOA (benzoxazolin-2(3H)-one), the predominant $\mathrm{BX}$ degradation product [32], is transformed by soil borne bacteria into 2-amino-phenoxazin-3-one (APO) that is even more phytotoxic in bioassays [33]. All BOA present in an extract is typically assumed to be a degradation product of DIBOA, itself a degradation product of the DIBOA-glycoside that was stored in the vacuole [32].

The use of allelochemicals to manage weeds can theoretically be achieved by one of two approaches. One method involves the use of crops that possess and deliver allelochemicals by root exudation during growth in the field [8]. Alternatively, allelopathic cover crops can be utilized. These are killed prior to planting the main crop, and both the allelochemicals leached from the living cover crop and those released from the resulting mulch act to suppress weeds. The time of kill varies depending on soil and temperature conditions, as well as susceptibility of the spring crop to the physical/chemical properties of the cover crop, that is, its ability to emerge through a layer of residues or withstand allelopathic effects [19]. Uptake of allelochemicals from rye residue may be from direct contact with tissue fragments or through the soil. This study focuses on foliage leachates rather than root exudates because the residues, especially in no-tillage cropping systems, tend to be concentrated near the seed germination zone where they have a greater potential to chemically interfere with weed seedling growth [28].

The allelochemical concentration in rye tissue is not constant during the growing season. The BX concentration (mg. $\mathrm{g}^{-1}$ dry weight of tissue) in fall planted rye reaches a maximum soon after planting or in early spring, depending on weather conditions. In Maryland, USA, Rice et al. [15] observed a constant decrease in BX concentration in "Abruzzi" rye from November to June, whereas, in North Carolina, BX concentration in "Abruzzi" and other varieties decreased from March through May [14]. Not only does the $\mathrm{BX} / \mathrm{DIBOA}$ concentration change, but the phytotoxicity of the rye aqueous extract (as determined by bioassay) also changes over the season in a manner that largely parallels the $\mathrm{BX}$ content $[14,15,34]$. Unfortunately, accumulation profiles of potentially allelopathic secondary metabolites do not always coincide with the requirements of effective early season weed control at the time the main crop is planted [35]. Thus, the observed decrease in the allelochemical concentration in maturing rye combined with variations in the maturation rate due to annual variation in environmental factors could result in differences in the allelochemical content from year to year. These differences likely account for the inconsistent weed control sometimes reported for rye cover crops [36]. Teasdale et al. [37] have reported that although residues of fall planted rye incorporated in the soil the following spring inhibited indicator species growth, only low levels of most toxic BXs were detected in the soil. This suggested that other compounds may have been responsible for the observed phytotoxicity. At the time of sampling, however, measured tissue BX concentrations in that study were much lower than the values encountered at a comparable time in this study, as well as potential "field rates" (BX concentration $\times$ biomass/area). Although phytotoxic compounds other than BXs need to be investigated, the sheer amount of BXs synthesized by rye in North Carolina justifies that they are the focus of this study.

Weed control utilizing allelopathic cover crops is an attractive weed management option for both conventional and organic growers. The variation in weed suppressive efficacy of cover crop mulches indicates the need for better understanding of the chemical ecology of these systems. A clearer picture of the effects of the specific developmental, environmental, physiological, and genetic factors that regulate allelochemical production is needed to make such crops useful and reliable agronomic tools [38]. The goals of this research were to more fully characterize temporal changes in BX content of fall planted, field grown rye in order to obtain a better understanding of rye's natural allelopathic potential. In a previous field study in North Carolina [14], three time points, from March 1 to April 26, had been selected for tissue sampling, whereas the present study includes seven from February 6 to May 1 (only showing data for five since the last two showed no significant difference). Also, serial dilutions were made to determine the $\mathrm{D}_{50}$ of rye extracts for each time point, instead of a single dilution used to determine a percent inhibition rate. A different analytical method for tissue BX content was used: GC-FID instead of HPLC-Vis. Finally, a second year of trials was included in the study. This should, in turn, help optimize management or a variety of choices so allelochemical content in foliar tissues of rye cover crops provides better, more consistent weed control in the field.

\section{Materials and Methods}

2.1. Plant Material. Field experiments were conducted over a two-year period. In year one (2002-2003) rye was planted on November 15th at the Cherry Research Station near Goldsboro, NC, in a clay-loam soil that had previously been in pasture. Each variety was planted into $1.90 \times 18.3 \mathrm{~m}$ plots with a grain drill set for $18 \mathrm{~cm}$ row spacing and a depth of $4 \mathrm{~cm}$. Seeding rate was $100 \mathrm{~kg} \cdot \mathrm{ha}^{-1}$. Prior to planting, plots were fertilized with $90 \mathrm{~kg} \mathrm{~N} \cdot \mathrm{ha}^{-1}$ of nitrogen applied as ammonium nitrate (34-0-0). Rye varieties used are commonly planted in North Carolina by growers who chose to include cover crops in their rotation (Reberg-Horton, personal communication); they were the winter varieties "Wheeler" and "Aroostook," which require vernalization, as well as the facultative varieties "Wrens Abruzzi" and "Bonel," which do not require vernalization for initiation of flowering. Plots were distributed in a randomized complete block design with five replications. Shoot tissue was harvested on seven dates (Julian date (JD) in parentheses): February 6 (37), 15 (46), and 25 (56), March 6 (65) and 25 (84), April 12 (102), and May 1 (121) and processed as described below. 
TABLE 1: Soils analysis results for research plots at Cherry Research Station near Goldsboro, NC (year 1), and the Lake Wheeler Field Laboratory near Raleigh, NC (year 2). Analysis provided by the Environmental and Agricultural Testing Service at North Carolina State University.

\begin{tabular}{lcccccccrrrr}
\hline & Total C & Total N & P & K & Ca & $\begin{array}{c}\text { Mg } \\
\text { mg.kg }\end{array}$ & S & Cu & Mn & Zn \\
\hline Year 1 & 0.71 & & 0.06 & 468.58 & 243.90 & 562.57 & 220.89 & 80.68 & 1.78 & 18.20 & 7.05 \\
Year 2 & 0.53 & 0.05 & 450.28 & 225.03 & 387.06 & 237.96 & 74.81 & 1.52 & 36.95 & 6.06 \\
\hline
\end{tabular}

The second-year experiment (2005-2006) was conducted to better characterize the decline in BX content and allelopathic potential of rye tissue that occurs in March in North Carolina. Rye was planted on December 3 at the Lake Wheeler Field Laboratory near Raleigh, NC, also in a clayloam soil that had been in pasture. Plot size, fertilizer, seeding rate, row spacing, and planting depth were as described above. Rye varieties used were "Aroostook," "Wheeler" (winter types), and "Wrens Abruzzi" (facultative type). Plots were distributed in a randomized complete block design with five replications. Shoot tissue was harvested on five dates (Julian date in parentheses): March 2 (61), 11 (70), 17 (76), 24 (83), and 31 (90) and processed as described below. Soil analysis results for both test sites are presented in Table 1.

2.2. Tissue Harvest, Handling, and Storage. Tissue was harvested from a $0.5 \mathrm{~m}^{2}$ area by cutting the stems just above the soil surface. Tissue was then oven dried at $60^{\circ} \mathrm{C}$ for 3 days, ground to a powder in a Wiley mill with a $1 \mathrm{~mm}$ screen, and stored at $-20^{\circ} \mathrm{C}$ pending analysis. Samples were used both for determining BX concentration and in bioassays. The harvest and storage methods used here provided a reliable, reproducible source of tissue for both bioassay and chemical analyses of the relatively large quantities of field grown plants $[14,15,34]$. Preliminary assessment found minimal variation in BX levels when comparing tissues that were flash-frozen and then freeze dried to those that were oven dried as described above (not shown). In addition, dried, ground tissue showed no differences over time for either bioassays or $\mathrm{BX}$ analyses when stored at $-20^{\circ} \mathrm{C}$. Further, although DIBOA and other BXs have been reported to be unstable in aqueous solution [32], they appear to be much more stable in plant tissue. In fact, Yenish et al. [35] reported that only $50 \%$ of the BX content in field rye tissue had disappeared 10 to 12 days after being cut and let in fiberglass mesh bags in the field.

2.3. Bioassay of Rye Allelopathic Potential. In preliminary trials, minimal differences in phytotoxicity were observed for tissue extracts from the last three sampling dates of the first year. Thus, only tissues from the first five harvests were used for bioassays. To assess changes in the allelopathic potential of rye foliage over time, the $\mathrm{D}_{50}$ (dilution of extract that inhibits indicator species root elongation by $50 \%$ compared to a water only control) was calculated from serial dilutions of the extract. The $\mathrm{D}_{50}$ value was derived from the equation assigned to the curve best fitting the relationship between root elongation (percent of control) and the dilution $\left(\mathrm{mL} \cdot \mathrm{g}^{-1}\right)$. All pairwise comparisons were adjusted with the TukeyKramer method. One gram of ground tissue was added to
$50.0 \mathrm{~mL}$ of deionized water and extracted by agitation on an orbital shaker for $1 \mathrm{~h}$. The extract was then vacuum-filtered through Whatman number 1 filter paper and its $\mathrm{pH}$ was measured. It was then stored for up to $12 \mathrm{~h}$ at $4^{\circ} \mathrm{C}$ or at $-20^{\circ} \mathrm{C}$ for longer periods prior to bioassay. Serial dilutions of the filtered extract ranged from 1:50 to 1:1600. Aliquots $(5.0 \mathrm{~mL})$ of the diluted extract were added to $90 \times 15 \mathrm{~mm}$ round Petri dishes containing two Whatman number 1 filter papers, and each dilution was run in duplicate. Ten seeds of redroot pigweed (Amaranthus retroflexus) or perennial ryegrass (Lolium perenne) were placed on the filter papers and the dishes were sealed with Parafilm and incubated in a germination chamber at $28^{\circ} \mathrm{C}$ in the dark. Root elongation of each seedling was measured to the nearest $\mathrm{mm}$ after $72 \mathrm{~h}$.

2.4. Determination of $B X$ Content. The benzoxazinone content of tissues was analyzed by GC [38]. Dried rye shoot tissue $(0.5 \mathrm{~g}$, see above) was extracted in $10.0 \mathrm{~mL}$ of $50 \%$ ethanol in a $75 \mathrm{~mL}$ SPE (solid phase extraction) reservoir (Alltech Associates, Deerfield, IL) fitted with a bottom frit ( $20 \mu$ porosity). Samples were vortexed for $1 \mathrm{~min}$ and the resulting extract was then filtered through the reservoir using a vacuum manifold (VWR Scientific, West Chester, PA). The extracted tissue was then washed with $5.0 \mathrm{~mL}$ of deionized (DI) water and filtered under vacuum until the plant tissue was dry. The ethanol filtrate was transferred to a volumetric flask and brought to $25.0 \mathrm{~mL}$ with DI water. A $10.0 \mathrm{~mL}$ aliquot of the filtrate was partitioned three times against equal volumes $(5.0 \mathrm{~mL})$ of ethyl acetate (EtOAc). The EtOAc extracts were combined and dried overnight with anhydrous sodium sulfate. A $10.0 \mathrm{~mL}$ aliquot of the resulting anhydrous EtOAc extract was mixed with $750 \mu \mathrm{L}$ of a $200 \mu \mathrm{g} / \mathrm{mL}$ octadecanol internal standard dissolved in toluene and the resulting mixture reduced to dryness under a $\mathrm{N}_{2}$ stream at $40^{\circ} \mathrm{C}$. The dried residue was dissolved in $400 \mu \mathrm{L}$ of $1: 1 \mathrm{MSTFA}-\mathrm{DMF}$ (derivatization agent N-methyln-trimethylsilyltrifluoroacetamide and dimethylformamide solvent), capped under $\mathrm{N}_{2}$, and heated at $75^{\circ} \mathrm{C}$ for $30 \mathrm{~min}$. The resulting derivatized solutions were then transferred to autosampler vials and a septum cap was attached. Compounds in the plant extracts were then analyzed and quantified using an Agilent 6890N gas chromatograph (Agilent Technologies, Santa Clara, CA) equipped with a $30 \mathrm{~m}$ DB- 5 column $(0.32 \mathrm{~mm}$ diameter, $1.5 \mu \mathrm{m}$ film thickness, J\&W Scientific, Agilent Technologies, Santa Clara, CA) and an Agilent 7683 autosampler. Derivatized samples $(0.5 \mu \mathrm{L})$ were introduced using splitless injection with an injector temperature of $250^{\circ} \mathrm{C}$ and separated using a helium (UHP) carrier gas linear velocity of $43.0 \mathrm{~cm} \cdot \mathrm{s}^{-1}$. The initial oven 
temperature was $100^{\circ} \mathrm{C}$, followed by a $5^{\circ} \mathrm{C} / \mathrm{min}$ increase to a final temperature of $300^{\circ} \mathrm{C}$. The oven temperature increase began upon injection, and the final temperature was maintained for $30 \mathrm{~min}$. Flame ionization detection was utilized with a detector temperature of $325^{\circ} \mathrm{C}$, and data were collected using a PerkinElmer TotalChrom 6.2 data system (PerkinElmer, Waltham, MA). Peaks were quantified by comparison to internal standards using appropriate multilevel calibration curves for BOA (benzoxazolin-2(3H)one), DIBOA (2,4-dihydroxy-2H-1,4-benzoxazin-3(4H)one), and DIBOA-Glu (2(2,4-dihydroxy-2H-1,4-benzoxazin$3(4 H)$-one)- $\beta$-D-glucopyranoside). Limits of detection were $173.8 \mathrm{pmol} /$ injection for $\mathrm{BOA}, 16.13 \mathrm{pmol} /$ injection for DIBOA, and $72.38 \mathrm{pmol} /$ injection for DIBOA-Glu [40]. The DIBOA and DIBOA-Glu standards were prepared in Dr. W. S. Chilton's and Dr. D. A. Danehower's Laboratories, respectively, at NC State University [40]. The BOA standard was purchased from Sigma-Aldrich (St. Louis, MO).

2.5. Statistical Analysis. Data were analyzed over time using a PROC MIXED repeated measures ANOVA model using SAS Software Version 9.1.3 (SAS Institute Inc., 2000-2004) with the Tukey adjustment method to test for significance of differences among varieties and sampling dates. Normality of data was verified using the univariate procedure and homogeneity of variance was confirmed using Levene's test.

\section{Results}

3.1. Phytotoxicity of Rye Extracts. Previous analyses of rye tissue phytotoxicity were based on single dilution bioassays that did not anticipate the dramatic changes in phytotoxicity that were observed over the experimental season [14]. To make more accurate comparisons over these large changes in toxicity, both pigweed and perennial ryegrass seeds were set to germinate on serial dilutions of crude aqueous tissue extracts. The inhibition of germination and growth of the seedlings were compared to a water control, and the dilution that inhibited growth by $50 \%\left(\mathrm{D}_{50}\right)$ was calculated. Germination rates in the controls were $92.5 \%$ and $97.5 \%$ for pigweed and ryegrass, respectively. Ungerminated seeds, which showed no root growth, were included in the growth measurement pool (i.e., their root elongation was equal to zero). $\mathrm{pH}$ of extracts was measured for the initial dilution and proved to be similar across sampling dates (data not shown). Preliminary bioassays were conducted to estimate a suitable range of dilutions, and replicate bioassays were then conducted at dilutions that would bracket the $\mathrm{D}_{50}$. The second-year field experiment focused on the latter part of the season (in March, JDs 60 and 90) to obtain a more precise measurement of the change in rye leaf tissue phytotoxicity and benzoxazinone content during their decline phase.

3.2. Bioassay Using Pigweed as an Indicator. For the first year's pigweed bioassays (2002-2003), seed germination and root elongation were sensitive to aqueous extracts from all rye varieties tested (Figure 1). The phytotoxicity of these extracts decreased as the season progressed, with the apparent rate

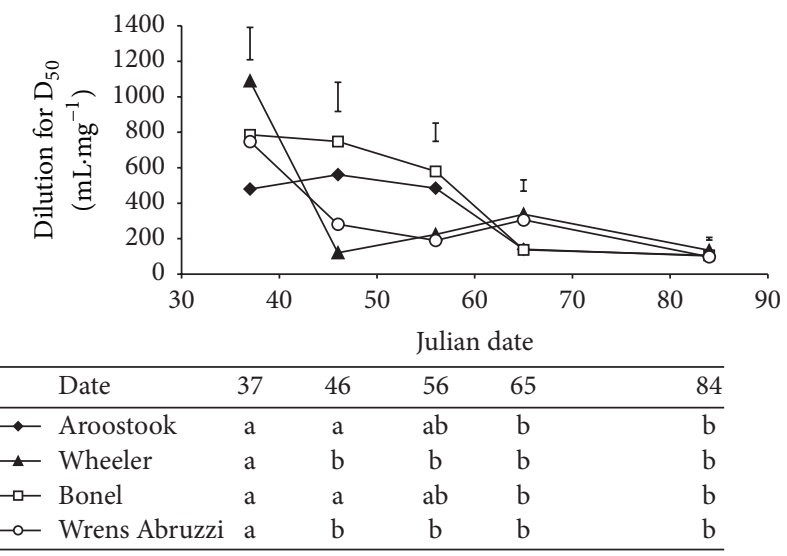

FIGURE 1: Inhibition of pigweed germination and growth by extracts of four field grown rye varieties, harvested at five different dates (Julian dates) during the spring of the first year of experiments. $\mathrm{D}_{50}$ is the concentration required to cause $50 \%$ growth inhibition. Significant differences over time within each variety according to the Tukey-Kramer method $(p<0.05)$ are indicated by different letters. Vertical bars represent standard errors at each sampling date.

of decrease varying among varieties. As noted above, preliminary trials showed minimal differences in phytotoxicity for tissue extracts from the last two sampling dates (April 12 and May 1; JD 102 and 121, resp.); therefore only tissues from the first five harvests were fully assessed. For "Aroostook" and "Bonel," extracts from the first three harvest dates (February 6, 15, and 25; JDs 37, 46, and 56, resp.) were the most phytotoxic. The phytotoxicity of the extracts from these varieties then decreased at the fourth harvest on March 6 (JD 65) and remained at that level through the harvest on March 25 (JD 84). For "Wheeler" and "Wrens Abruzzi," extracts from the first harvest date were the most phytotoxic, with toxicity decreasing by the second harvest and remaining low until the last harvest. For each individual sampling date, there was no difference in phytotoxicity between varieties except at the first and second harvest dates. During the second year (2005-2006), pigweed bioassays between March 2 and 31 (JDs 61 through 90) showed a lesser decline in phytotoxicity over time (Figure 2) and showed no significant differences between varieties. Phytotoxicity was the same on March 6 and 11 (JDs 61 and 70) and then decreased on March 17 (JD 76) to a minimum that remained stable until the last sampling on March 31 (JD 90). Phytotoxicity values in the second year were similar to those measured in the first year during equivalent sampling periods, except for the first sampling on March 2 (JD 61) when Bonel and Aroostook had much lower toxicity than at the same time the first year.

3.3. Bioassay Using Ryegrass as an Indicator. In the firstyear ryegrass bioassays, seed germination and root elongation were also sensitive to aqueous extracts of all rye varieties (Figure 3), with varying sensitivities according to the rye variety. For "Aroostook" extracts from the first two harvests (February 6 and 15; JDs 37 and 46) were the most phytotoxic. Phytotoxicity then decreased at the third harvest February 25 (JD 56) and remained low until the last harvest on 


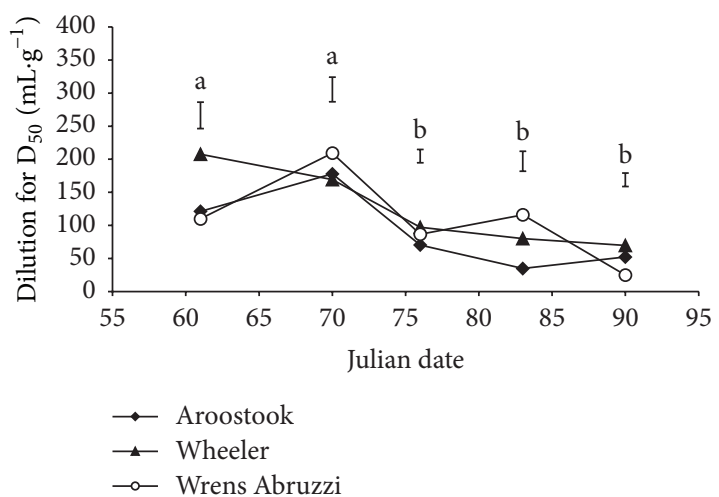

FIGURE 2: Inhibition of pigweed germination and growth by extracts of three field grown rye varieties, harvested at five different dates (Julian dates) during the spring of the second year of experiments. $\mathrm{D}_{50}$ is the concentration required to cause $50 \%$ growth inhibition. Values associated with the same letter are not significantly different according to the Tukey-Kramer method $(p<0.05)$. Vertical bars represent standard errors at each sampling date.

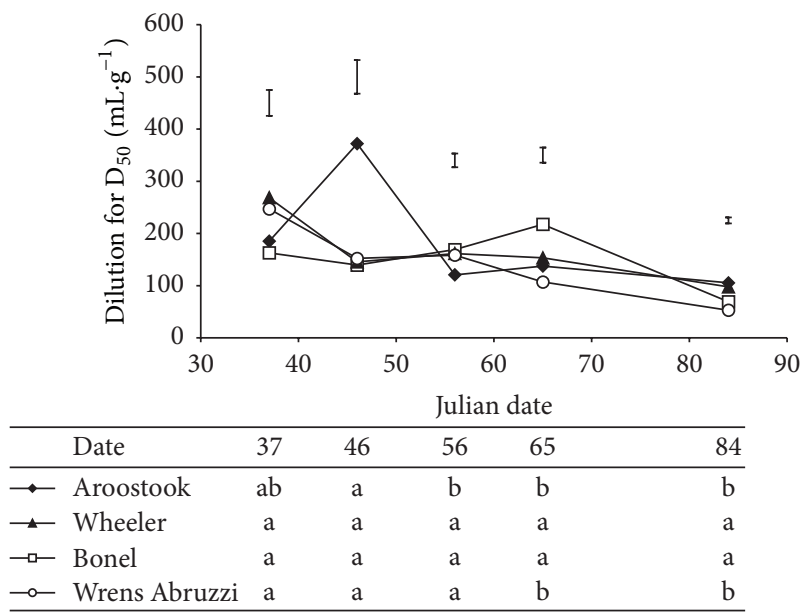

FIGURE 3: Inhibition of ryegrass germination and growth by extracts of four field grown rye varieties, harvested at different dates (Julian dates) during the spring of the first year of experiments. $D_{50}$ is the concentration required to cause $50 \%$ growth inhibition. Significant differences over time within each variety according to the TukeyKramer method $(p<0.05)$ are indicated by different letters. Vertical bars represent standard errors at each sampling date.

March 25 (JD 84). For "Wrens Abruzzi," extracts from the first three harvests were the most phytotoxic. Phytotoxicity then decreased at the fourth harvest (March 6; JD 65) and remained stable until the last sampling date. There were no significant variations in phytotoxicity of "Bonel" or "Wheeler" over the duration of the experiment. For each individual sampling date, there was generally no difference in phytotoxicity between varieties except at the second harvest (March 11; JD 70), when "Aroostook" extracts were significantly more phytotoxic than those of all other varieties $(p \leq 0.01)$.

The relatively constant, low levels of ryegrass phytotoxicity observed between March 6 and 25 (JDs 65 and 84 ) in year 1 of the study were essentially reproduced by

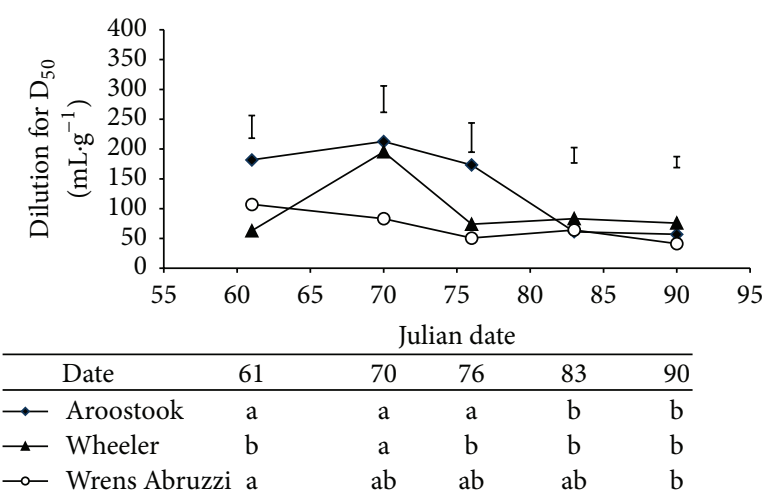

FIGURE 4: Inhibition of ryegrass germination and growth by extracts of three field grown rye varieties, harvested at five different dates (Julian dates) during the spring of the second year of experiments. $\mathrm{D}_{50}$ is the concentration required to cause $50 \%$ growth inhibition. Values associated with the same letter are not significantly different according to the Tukey-Kramer method ( $p<0.05)$. Vertical bars represent standard errors at each sampling date.

the second-year results (Figure 4), but at later sampling dates. In contrast, however, although extracts from all rye varieties were inhibitory to ryegrass seed germination and root elongation during the second year, significant differences between varieties were observed $(p=0.05)$. Phytotoxicity of "Aroostook" extracts was maximal and equivalent on March 2 through March 17 (JDs 61, 70, and 76), then decreased on March 24 (JD 83), and remained stable until the last sampling on March 31 (JD 90). Phytotoxicity of "Wheeler" extracts increased, for reasons that are unclear, between March 2 and 11 (JDs 61 and 70) then returned to its initial level March 17 (JD 76) to remain stable until the last sampling date. Finally, phytotoxicity of "Wrens Abruzzi" extracts gradually decreased between JDs 61 and 90, with no significant difference between March 2 and 24 (JDs 61 to 83).

3.4. Benzoxazinone Content. In the first year of this study, BX levels in extracts of rye shoot tissue varied during the season (Figure 5). BX concentrations were similar among varieties at all dates except for Wrens Abruzzi, for which higher values than other varieties were measured at the first two harvest dates and lower values were measured at the third harvest date. Maximum concentrations of BX were found in all varieties by the first week in March (JD 65), with levels decreasing to a minimum by the next sampling date (March 25; JD 84).

In the second year, BX concentrations decreased over the month of March (JDs 61 and 90) (Figure 6), with no significant difference observed between varieties $(p=0.79)$. BX concentrations were similar from March 2 to 17 (JDs 61 and 76), then decreased by March 24 (JD 83), and remained the same thereafter.

As with the bioassays, BX profiles varied between years one and two of the study. The average BX concentration for the initial harvest in year two $\left(925 \mu \mathrm{g} \cdot \mathrm{g}^{-1}\right.$ dry wt. at JD 61; Figure 6) was much lower than at a similar date in year one (1902 $\mu \mathrm{g} \cdot \mathrm{g}^{-1}$ dry wt. at JD 65; Figure 5). By March 25 (JD 84), 


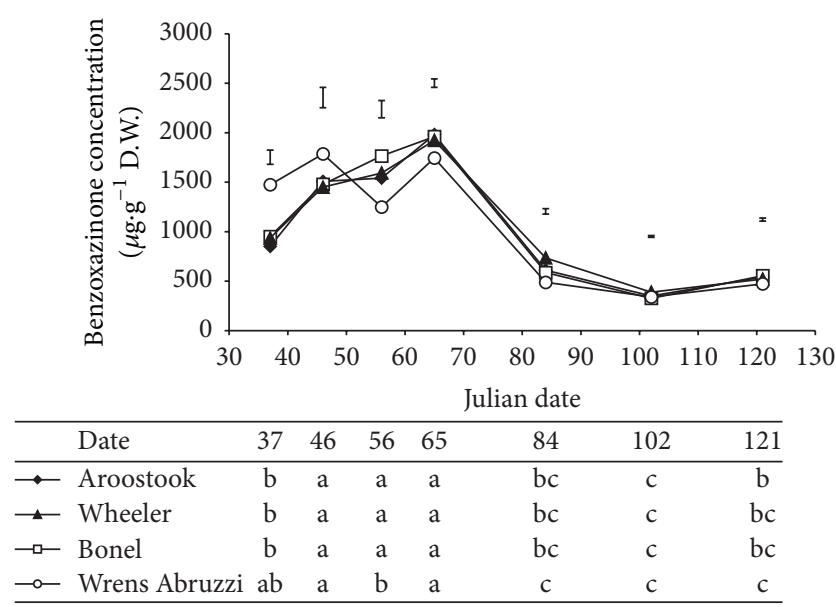

FIGURE 5: Variation of total benzoxazinone concentration (sum of DIBOA-glucoside, DIBOA, and BOA) in shoot tissue of four rye cultivars between dates 37 and 121 (Julian dates) during the first year of experiments. Significant differences over time within each variety according to the Tukey-Kramer method $(p<0.05)$ are indicated by different letters. Vertical bars represent standard errors at each sampling date.

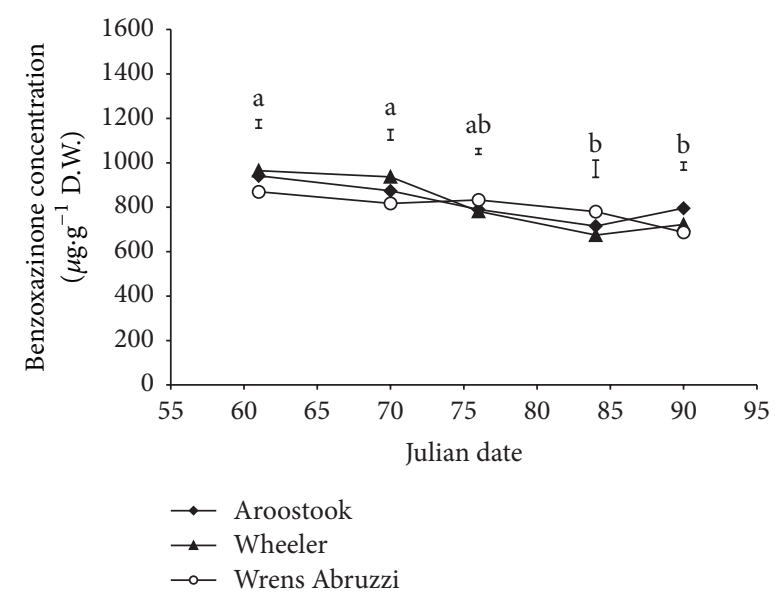

FIGURE 6: Variation of total benzoxazinone content (sum of DIBOAglucoside, DIBOA, and BOA) in shoot tissue of three rye cultivars between dates 61 and 90 (Julian dates) of the second year of experiments. Values associated with the same letter are not significantly different according to the Tukey-Kramer method $(p<0.05)$. Vertical bars represent standard errors at each sampling date.

however, average BX content was similar (year 2: $723 \mu \mathrm{g} \cdot \mathrm{g}^{-1}$ dry wt. on JD 83 (Figure 6); year 1: $605 \mu \mathrm{g} \cdot \mathrm{g}^{-1}$ dry wt. at JD 84 (Figure 5)). The differences between year one and year two are likely due, at least in part, to later planting in the second year caused by weather constraints. Consequently, the initial harvest in year two was delayed (Figure 7) to obtain an adequate sample size. In addition, temperatures in year two were higher than in year one (Figures 8 and 9), resulting in a significant increase in growing degree days (GDDs; Figure 7). As a result, at corresponding dates after planting, plants in year two had accumulated from 27 to $48 \%$ more GDDs than in year one.
The highest BX concentrations observed here were in year one and ranged from 1744 to $1981 \mu \mathrm{g} \cdot \mathrm{g}^{-1}$ dry tissue (Figure 5). In year two, the highest BX concentrations ranged from 870 to $965 \mu \mathrm{g} \cdot \mathrm{g}^{-1}$ dry tissue (Figure 6).

3.5. Total Field Accumulation of BX. The total amount of BX in a field at any time depends on both the concentration in the plant and the total plant biomass. Total dry matter accumulation for different rye varieties throughout the growing season was recorded. In year one (Figure 10), "Wheeler" accumulated dry matter more slowly than "Bonel" $(p=$ $0.015)$ or "Wrens Abruzzi" ( $p=0.001)$. In contrast, the other winter variety "Aroostook" showed no significant difference in biomass accumulation from other varieties.

Although the tissue concentration of $\mathrm{BX}$ reached a maximum in early March (JD 65) and then decreased over the remainder of the season (Figure 5), the continued accumulation of biomass resulted in two peaks of total field BX (Figure 11). These two peaks occurred in early March (JD 65) and early May (JD 121) with BX "rate" ranging from 3.0 to $5.0 \mathrm{~kg} \cdot \mathrm{ha}^{-1}$ at each of these points in time. The first peak in early March (JD 65) corresponded to the maximum concentration of $\mathrm{BX}$ in rye leaf tissue and occurred during the transition from vegetative to reproductive growth. The second peak (JD 121) was on the last sampling date, when maximum biomass was recorded. Although the BX concentration in rye tissue at the end of the growing season had decreased to about $1 / 4$ of its early season maximum, total BX field accumulation was at its maximum due to the large accumulation of above ground biomass. All varieties accumulated equivalent total BX per hectare throughout the experiment, with the exception of "Wheeler," which had accumulated less dry matter by the last sampling date (Figure 10).

In year two total BX per hectare increased steadily over the sampling period (Figure 12), with no statistically significant differences between varieties for either total field BX or dry matter accumulation (Figure 13). Total BX per ha was low through early March (JDs 61 to 70). In midMarch (JD 76) total BX for "Aroostook" and "Wrens Abruzzi" began to increase and continued to increase through the end of March (JD 90). Increase in total field BX for "Wheeler" increased after mid-March (JD 76).

\section{Discussion}

4.1. Bioassays Show Maximum Toxicity prior to Reproductive Growth. In year one, phytotoxicity of extracts from field grown rye tissue varied depending on the variety, harvest date, and indicator species used (Figures 1 and 3). In general, not only were extracts from tissues harvested earlier in the season more phytotoxic than those harvested later, but greater variation was seen between varieties. In addition, extracts from the earliest harvests inhibited pigweed root elongation more than ryegrass root elongation. This corresponds with previous reports indicating that dicot species are typically more sensitive than monocots to rye allelochemicals [20, 41]. However, phytotoxicity of extracts of all varieties at 


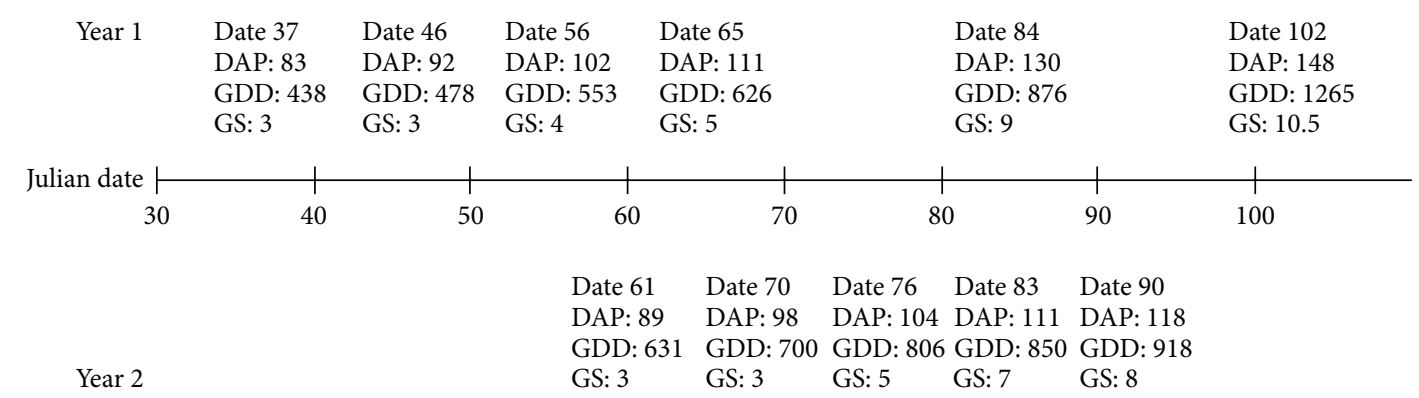

FIGURE 7: Accumulated days after planting (DAP), growing degree days (GDD), and observed Feekes growth stage (GS, for variety Aroostook) at successive sampling dates (Julian dates) for year one and year two of the field experiment.

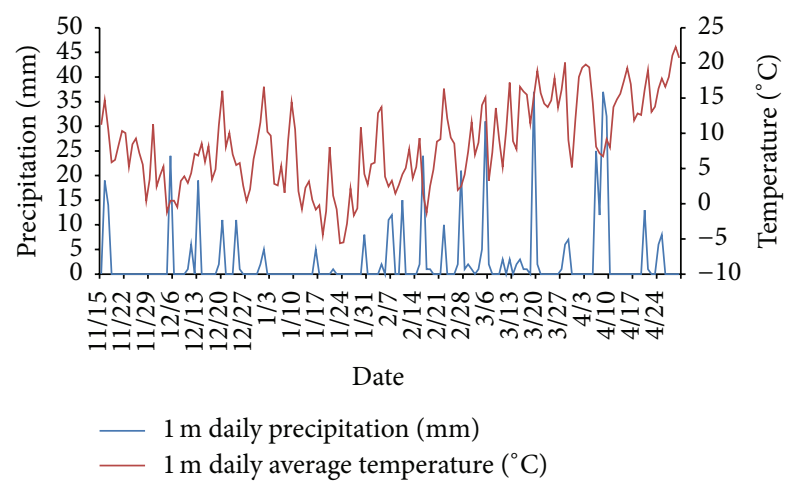

FIGURE 8: Average daily precipitation and temperature values recorded at the Cherry Research Station near Goldsboro, NC, during year 1.

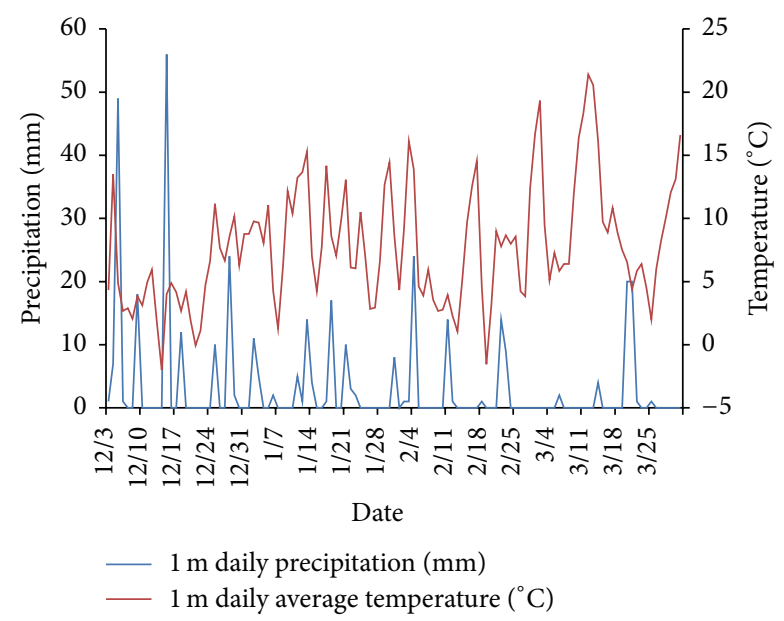

FIGURE 9: Average daily precipitation and temperature values recorded at the Lake Wheeler Field Laboratory near Raleigh, NC, during year 2.

the third, fourth, and fifth harvests was much lower and was essentially the same for both pigweed and ryegrass bioassays. Extracts from tissues harvested in the second year between the beginning and end of March showed low and generally decreasing levels of phytotoxicity, similar to those seen over the comparable period in year 1 and consistent with the results of previous abbreviated analyses [14, 15]. The greater detail provided by the present study revealed that the maximum

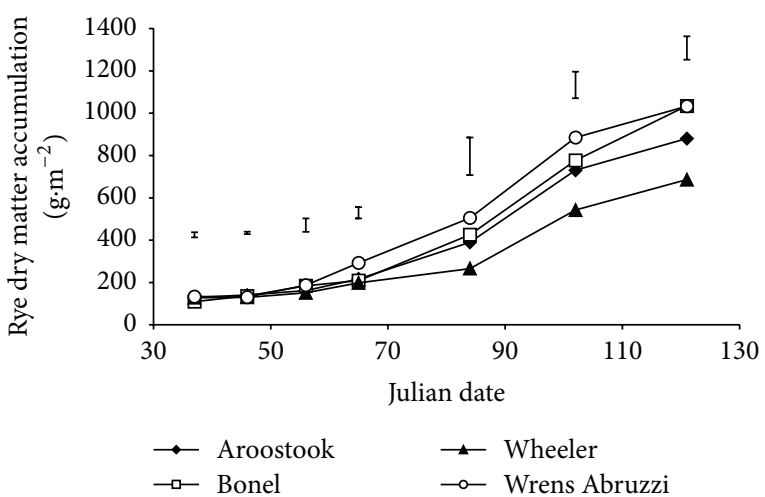

FIGURE 10: Accumulation of above ground dry matter in four rye varieties over time (Julian dates) during the first year of experiments. Vertical bars represent standard errors at each sampling date.

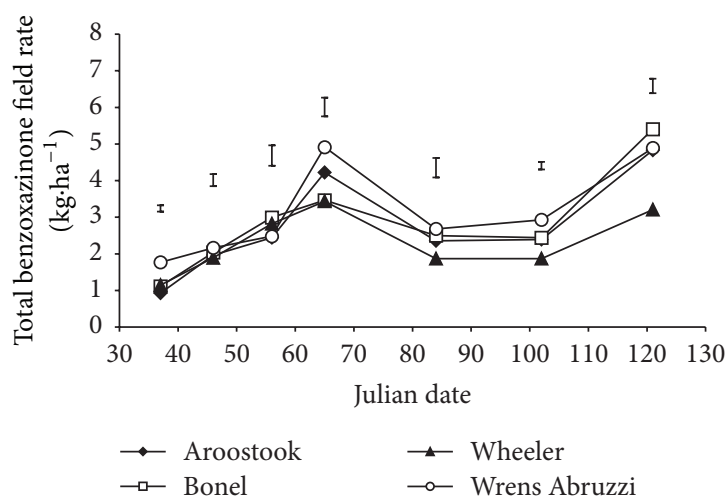

FIGURE 11: Benzoxazinone rate (concentration $\times$ biomass) at successive dates in rye foliage of four rye varieties during the first year of experiments. Vertical bars represent standard errors at each sampling date.

phytotoxicity of rye plant extracts occurred when plants were at stage 3 or stage 4 of the Feekes scale, just prior to the transition from vegetative to reproductive growth [39] (Figures 1 and 2; Table 2).

\subsection{Benzoxazinone in Tissues Is Also Maximal prior to Initia-} tion of Reproductive Growth. The range of BX concentrations measured in this study is commensurate with findings by other groups: In studies by Burgos et al. [34] field grown shoot 


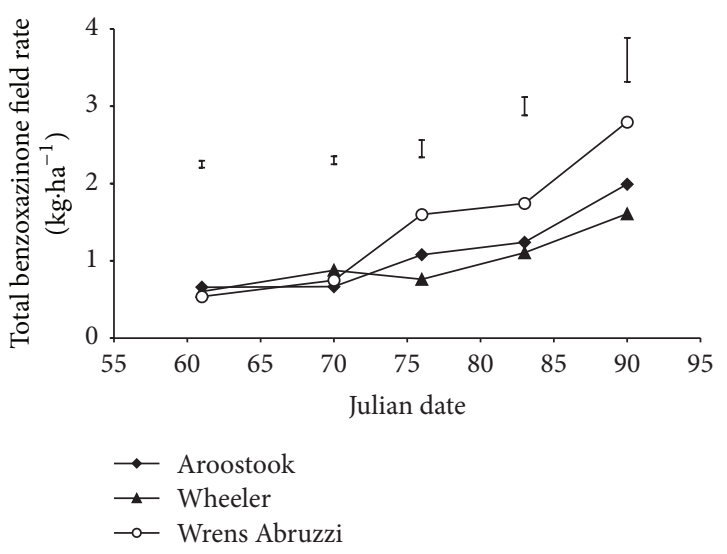

FIGURE 12: Benzoxazinone field rate (concentration $\times$ biomass) at successive dates in rye foliage of four rye varieties during the second year of experiments. Vertical bars represent standard errors at each sampling date.

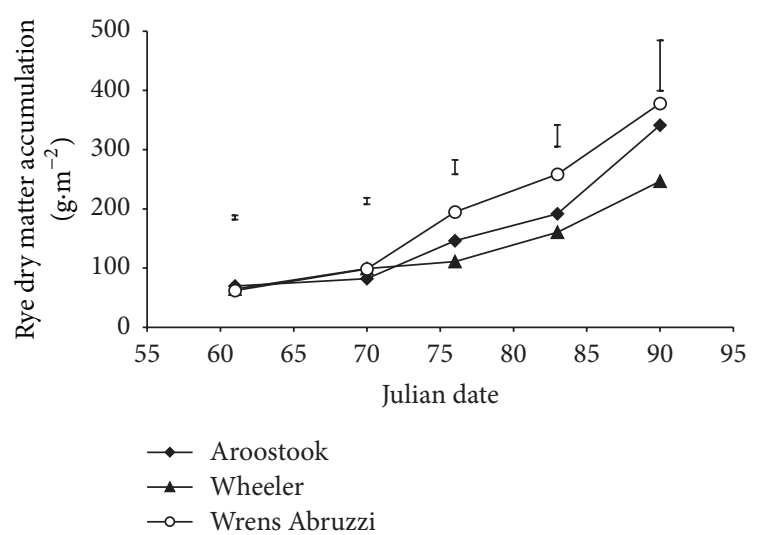

FIGURE 13: Accumulation of dry matter for three rye varieties over time (Julian dates) during the second year of experiments. Vertical bars represent standard errors at each sampling date.

tissue of various varieties (planted on October 22 in Arkansas, harvested on April 30, at Feekes 10) had 137 to $1240 \mu \mathrm{g} \cdot \mathrm{g}^{-1} \mathrm{dry}$ tissue total BX. "Abruzzi" rye planted in mid-September in Maryland contained a maximum total BX of $404 \mu \mathrm{g} \cdot \mathrm{g}^{-1} \mathrm{dry}$ tissue in early November [15]. In North Carolina, four rye varieties planted in mid-November had 1000 to $1800 \mu \mathrm{g} \cdot \mathrm{g}^{-1}$ dry tissue DIBOA [14] and, in Denmark, thirteen springharvested (Feekes 7 to 8 ) varieties had an average total BX of $1944 \mu \mathrm{g} \cdot \mathrm{g}^{-1}$ dry tissue [40].

In our analyses, the primary $\mathrm{BX}$ found in tissues was DIBOA-glycoside. Some DIBOA aglycone and BOA were also present (data not shown), but the proportion of each varied only slightly over the sampling period. This variation was likely not entirely due to phenological differences, as sample handling and processing can also independently affect BX stability.

In fact, the observed composition of the tissue BX confirms the relative stability of BXs under the isolation and assay conditions used here.

In year $1, \mathrm{BX}$ concentrations in all varieties increased from the first harvest in early February (JD 37) to their
TABLE 2: Average growth stage (Feekes scale [39]) of different rye varieties observed at successive sampling dates during the first and second year of experiments ("Bonel" not used in the second year).

\begin{tabular}{cccccc}
\hline & \multirow{5}{*}{ Date } & \multicolumn{4}{c}{ Average growth stage (Feekes scale) } \\
& & Aroostook & Bonel & Wheeler & Wrens Abruzzi \\
\hline \multirow{6}{*}{ Year 1 } & 37 & 3 & 3 & 3 & 3 \\
& 46 & 3 & 3 & 3 & 4 \\
& 56 & 4 & 4 & 3 & 4 \\
& 65 & 5 & 5 & 4 & 6 \\
& 84 & 9 & 9 & 8 & 10.1 \\
& 102 & 10.5 & 10.5 & 10.4 & 10.5 \\
& 121 & 10.54 & 10.54 & 10.53 & 10.54 \\
\hline \multirow{6}{*}{ Year 2 } & 61 & 3 & - & 3 & 3 \\
& 70 & 3 & - & 3 & 4 \\
& 76 & 5 & - & 3 & 7 \\
& 83 & 7 & - & 4 & 8 \\
\hline
\end{tabular}

highest levels at the end of the first week in March (JD 65). Although this generally mirrors the higher levels of phytotoxicity seen in bioassays of tissues harvested earlier in the season, there is not an exact correlation. For instance, phytotoxicity is already at its highest level in the assays from the first harvest in early February while BX levels are still increasing. Additionally, although BX profiles of the various varieties were quite similar, "Aroostook" and "Bonel" remained phytotoxic through the end of February, while toxicity of "Wrens" and "Wheeler" begins to decrease much earlier. Given the similarities in BX concentration profiles of the various varieties, this seems unlikely to be caused solely by differences in the decline of BX accumulation and suggests that compounds other than BXs are also involved in extract toxicity. Although not measured in this study, reports do indicate that rye contains other phytotoxic compounds including phenolics and organic acids [22, 37, 40]; in a study reported by Teasdale et al. [37], BXs contributed very little to toxicity measured in assays where rye was incorporated to field soil. The plants in that study, however, had much lower BX concentrations at kill time (145 to $161 \mu \mathrm{g} \cdot \mathrm{g}^{-1}$ for the first year and 12 to $55 \mu \mathrm{g} \cdot \mathrm{g}^{-1}$ for the second year) than what was measured in this study at the end of the sampling season (472 to $554 \mu \mathrm{g} \cdot \mathrm{g}^{-1}$ for the first year and 687 to $795 \mu \mathrm{g} \cdot \mathrm{g}^{-1}$ for the second year, albeit at an earlier developmental stage) and much lower field rates of BX $\left(0.9 \mathrm{~kg} \cdot \mathrm{ha}^{-1}\right.$ and $0.08 \mathrm{~kg} \cdot \mathrm{ha}^{-1}$ for the first and second years, resp.) than calculated in this study (3.21 to $5.41 \mathrm{~kg} \cdot \mathrm{ha}^{-1}$ and 1.6 to $2.79 \mathrm{~kg} \cdot \mathrm{ha}^{-1}$ for the first and second years, resp.).

The change from vegetative to reproductive growth correlated even more clearly with the large decrease in BX concentration in all varieties seen between March 6 (JD 65; Feekes stages 4 to 6) and March 25 (JD 84), at which time all varieties were into reproductive growth (Feekes of 8 and 10.1; Table 2). In year two, the decline was not as dramatic, but BX levels did decrease as reproductive growth progressed. The change from vegetative to reproductive growth is known to 
initiate reallocation of assimilated $\mathrm{C}$ and $\mathrm{N}$ from older leaves to developing reproductive tissues [42]. Thus the observed decrease in BX content coinciding with the onset of reproductive growth might reflect such metabolic reallocation to the reproductive tissue.

The specific roles of growth stage and leaf senescence in secondary metabolite and allelochemical content in plants have not been extensively explored. However, it is well known that when cereal grasses and other plants shift from vegetative to reproductive growth, they begin a patterned reallocation of accumulated $\mathrm{C}$ and $\mathrm{N}$ products from older leaves to the flowering tissue. For instance, the programmed catabolism of chlorophyll and photosynthetic proteins and the remobilization of the recycled $\mathrm{C}$ and $\mathrm{N}$ to reproductive tissues are characteristic of this transition [43-46]. Thus, one might expect a similar reallocation or directed export of accumulated defense compounds and a resultant decrease in levels of these compounds in the senescing tissue. Interestingly, current data on secondary metabolites in senescing leaves in other plants indicate that the content of at least some of these compounds increases [43, 46, 47]. For example, higher levels of flavonoid and anthocyanin secondary metabolites and/or increased specific expression of their biosynthetic genes have been observed in senescing leaves of Arabidopsis and poplar $[42,45]$. This is hypothesized to be a response to an increased need for defense compounds during senescence, because senescing tissues are more susceptible to pathogens. Though there is no data for rye, senescence in the flag leaf of wheat is characterized by an increase in the expression of specific secondary metabolite genes, including BX2 and BX4 (P450 monooxygenases), BX6 (dioxygenase), and BX9 (UDP-glucosyltransferase), which are involved in BX biosynthesis [47]. In rice, a similar increase in serotonin levels and tryptophan biosynthetic pathway genes was observed in senescing flag leaves [46]. Although these results might lead us to expect that levels of BX or defense related secondary metabolites would increase during senescence and flowering, one actually sees a decrease in BX content at the whole plant level in rye and wheat [44] as flowering progresses. It is likely that comparisons of secondary metabolite levels in specific tissues (e.g., flag leaves) versus entire plants (which represent a range of tissue types at various stages of development) would clarify the issue.

4.3. Total Field BX. For effective weed suppression using rye mulches, there must be both enough biomass for physical suppression and enough allelochemical in the field to provide chemical competition at the time the main crop is to be planted. Total field BX, of course, depends on both BX concentration in the plant and total plant biomass. The extended, more detailed sampling conducted here allowed us to produce a better picture of these BX field "rates" throughout the season. Unfortunately the highest BX concentrations in rye are early in the season, presumably a time when rye uses BX to protect itself from biological competition. BX concentrations decrease thereafter and in previous studies (e.g., [14]) this was mirrored by a decrease in total field BX during later part of the season for all varieties. In contrast, field BX accumulation in the present study showed an increase at the end of the season due to an increase in biomass large enough offset lower shoot BX concentrations.

The variation observed between studies as well as from year to year within studies highlights some of the complexities inherent in using allelopathic cover crops for weed suppression. In addition to differences in tissue BX concentrations between two growing years, differences in biomass accumulation due to the potential impact of environmental variation, soils, and management practices impact BX content and stability in rye. Factors that affect both biomass accumulation and BX concentration can include planting date, rainfall, soil type, and drainage, as well as fertilization and soil microbiology. For example, the soil type in the Reberg-Horton et al. study [14] was a sandyloam, and some early desiccation of the older leaves was observed. This, in turn, likely decreased BX concentration in older, vegetative leaf tissue due to stress-induced desiccation and/or leaf abscission, while simultaneously decreasing total biomass. In contrast, the soils in the present study had a greater water holding capacity, and early desiccation was not observed (data not shown). Management practices, such as delaying rye control, allow for more biomass accumulation, therefore increasing ground cover and potentially reducing weed competition or increasing the interference with the emerging new crop $[48,49]$. The method of control, chemical or mechanical, may influence rye regrowth and also affect weed competition and new crop emergence [19]. Apart from variety selection, the amount of rye biomass present depends greatly on growing conditions throughout the fall and winter [50]. This enhances of course the unpredictable nature of a cover crop's efficiency to control weeds.

This and other studies underscore the need for management practices that optimize both biomass production and allelochemical production if we are to obtain consistent performance using rye as a cover crop. In fact, these studies suggest several potential management strategies for rye cover crops that could result in elevated levels of allelochemicals and enhanced weed suppression. One strategy would involve the late winter or early spring planting of a late maturing rye that has a high vernalization requirement. These conditions would delay or prevent flowering, and the resulting increase in the duration of vegetative growth should result in greater accumulation of BXs near the time of the spring planting dates. This approach, however, might reduce accumulated biomass and thus reduce the cover crop's ability to smother weeds via competition for light resources. Thus, the use of typically high biomass producers such as "Wheeler" might result in higher field BX levels late in the season. Although "Wheeler" did not show appreciably higher biomass or BX content in the present study, this appeared to be due to a delay in initial growth. This is perhaps because "Wheeler," a winter variety, is the latest maturing of the varieties tested (Table 2). "Wheeler," however, is in fact a high biomass producer [14] and would likely continue to accumulate biomass, reaching a maximum later than the other varieties.

Another possible management strategy would involve spring mowing of fall planted rye. The ensuing regrowth would result in the presence of younger tissue later in 
the season. This might also circumvent biomass issues. De Bruin et al. [48] reported that mowing early during vegetative growth has minimal impact on the regrowth potential of rye. An additional approach not previously available in cover crop allelopathy studies is the potential effect of "staygreen" genes, which delay leaf senescence [51]. Such a delay might also result in maintenance of allelochemical levels in vegetative tissues. This germplasm could be utilized alone or with either of the above management strategies.

In summary, this study not only confirms earlier reports of variations in allelochemical content in rye shoot tissue during the growing season, but also reveals a previously unobserved relationship between rye growth stage and allelochemical level. In addition, the use of tissue extract doseresponse bioassays combined with GC analysis of the same extracts established a parallel between allelochemical content and allelopathic potential. Although these results in themselves contribute to characterize allelopathic patterns in rye, the further implication that developmental and senescence processes have an impact on synthesis of BX in rye suggests exciting new avenues of exploration.

\section{Abbreviations}

BX: Benzoxazinone

DIBOA: 2,4-Dihydroxy-2H-1,4-benzoxazin-3(4H)-one

BOA: Benzoxazolin-2(3H)-one

JD: Julian date.

\section{Conflict of Interests}

The authors declare that there is no conflict of interests regarding the publication of this paper.

\section{Acknowledgments}

The authors thank Matthew Finney and Ken Fager for their technical assistance as well as Dr. D. Boos, Department of Statistics, NCSU, for help with the statistical analysis.

\section{References}

[1] L. A. Weston, "Utilization of allelopathy for weed management in agroecosystems," Agronomy Journal, vol. 88, no. 6, pp. 860866, 1996.

[2] M. E. Foley, "Genetic approach to the development of cover crops for weed management," Journal of Crop Production, vol. 2, no. 1, pp. 77-93, 1999.

[3] G. G. Nagabhushana, A. D. Worsham, and J. P. Yenish, "Allelopathic cover crops to reduce herbicide use in sustainable agricultural systems," Allelopathy Journal, vol. 8, no. 2, pp. 133146, 2001.

[4] National Organic Program, Code of Federal Regulations, Title 7: Agriculture, Part 205, National Organic Program, Washington, DC, USA, 2009.

[5] Inderjit and S. O. Duke, "Ecophysiological aspects of allelopathy," Planta, vol. 217, no. 4, pp. 529-539, 2003.
[6] L. A. Weston and S. O. Duke, "Weed and crop allelopathy," Critical Reviews in Plant Sciences, vol. 22, no. 3-4, pp. 367-389, 2003.

[7] T. L. Weir, S.-W. Park, and J. M. Vivanco, "Biochemical and physiological mechanisms mediated by allelochemicals," Current Opinion in Plant Biology, vol. 7, no. 4, pp. 472-479, 2004.

[8] R. G. Belz, "Allelopathy in crop/weed interactions-an update," Pest Management Science, vol. 63, no. 4, pp. 308-326, 2007.

[9] M. A. Czarnota, R. N. Paul, F. E. Dayan, C. I. Nimbal, and L. A. Weston, "Mode of action, localization of production, chemical nature, and activity of sorgoleone: a potent PSII inhibitor in Sorghum spp. root exudates," Weed Technology, vol. 15, no. 4, pp. 813-825, 2001.

[10] A. M. Hejl and K. L. Koster, "Juglone disrupts root plasma membrane $\mathrm{H}^{+}$-ATPase activity and impairs water uptake, root respiration, and growth in soybean (Glycine max) and corn (Zea mays)," Journal of Chemical Ecology, vol. 30, no. 2, pp. 453-471, 2004.

[11] A. Gierl and M. Frey, "Evolution of benzoxazinone biosynthesis and indole production in maize," Planta, vol. 213, no. 4, pp. 493498, 2001.

[12] A. Friebe, "Role of benzoxazinones in cereals," Journal of Crop Production, vol. 4, no. 2, pp. 379-400, 2001.

[13] Z. Huang, T. Haig, H. Wu, M. An, and J. Pratley, "Correlation between phytotoxicity on annual ryegrass (Lolium rigidum) and production dynamics of allelochemicals within root exudates of an allelopathic wheat," Journal of Chemical Ecology, vol. 29, no. 10, pp. 2263-2279, 2003.

[14] S. C. Reberg-Horton, J. D. Burton, D. A. Danehower et al., "Effect of time on the allelochemical content of ten cultivars of rye (Secale cereale L.)," Journal of Chemical Ecology, vol. 31, no. 1, pp. 179-192, 2005.

[15] C. P. Rice, B. P. Yong, F. Adam, A. A. Abdul-Baki, and J. R. Teasdale, "Hydroxamic acid content and toxicity of rye at selected growth stages," Journal of Chemical Ecology, vol. 31, no. 8, pp. 1887-1905, 2005.

[16] A. D. Worsham and U. Blum, "Allelopathic cover crops to reduce herbicide inputs in cropping systems," in Proceedings of the 1st International Weed Control Congress, vol. 2, pp. 577-579, Melbourne, Australia, February 1992.

[17] J. P. Barnes and A. R. Putnam, "Rye residues contribute to weed suppression in no-tillage cropping systems," Journal of Chemical Ecology, vol. 9, no. 8, pp. 1045-1057, 1983.

[18] K. N. Reddy, "Impact of rye cover crop and herbicides on weeds, yield, and net return in narrow-row transgenic and conventional soybean (glycine max)," Weed Technology, vol. 17, no. 1, pp. 28-35, 2003.

[19] L. R. Westgate, J. W. Singer, and K. A. Kohler, "Method and timing of rye control affects soybean development and resource utilization," Agronomy Journal, vol. 97, no. 3, pp. 806-816, 2005.

[20] J. P. Barnes and A. R. Putnam, "Evidence for allelopathy by residues and aqueous extracts of rye (Secale cereale)," Weed Science, vol. 34, no. 3, pp. 384-390, 1986.

[21] H. M. Niemeyer, "Hydroxamic acids derived from 2-hydroxy$2 H$-1,4-benzoxazin-3(4H)-one: fey defense chemicals of cereals," The Journal of Agricultural and Food Chemistry, vol. 57, no. 5, pp. 1677-1695, 2009.

[22] D. G. Shilling, L. A. Jones, A. D. Worsham, C. E. Parker, and R. F. Wilson, "Isolation and identification of some phytotoxic compounds from aqueous extracts of rye (Secale cereale L.)," Journal of Agricultural and Food Chemistry, vol. 34, no. 4, pp. 633-638, 1986. 
[23] A. Gierl, S. Gruen, U. Genschel, R. Huettl, and M. Frey, "Evolution of indole and benzoxazinone biosynthesis in Zea mays," in Recent Advances in Phytochemistry, vol. 38, chapter 4, pp. 69-83, Elsevier, 2004.

[24] M. Patel, R. J. McHugh Jr., B. C. Cordova et al., "Synthesis and evaluation of benzoxazinones as HIV-1 reverse transcriptase inhibitors. Analogs of Efavirenz (Sustiva)," Bioorganic and Medicinal Chemistry Letters, vol. 9, no. 22, pp. 3221-3224, 1999.

[25] P. J. Rybczynski, R. E. Zeck, D. W. Combs et al., "Benzoxazinones as PPAR $\gamma$ agonists. Part 1: SAR of three aromatic regions," Bioorganic \& Medicinal Chemistry Letters, vol. 13, no. 14, pp. 2359-2362, 2003.

[26] W. Huang, P. Zhang, J. F. Zuckett et al., "Design, synthesis and structure-activity relationships of benzoxazinone-based factor Xa inhibitors," Bioorganic and Medicinal Chemistry Letters, vol. 13, no. 3, pp. 561-566, 2003.

[27] T. R. Belliotti, D. J. Wustrow, W. A. Brink et al., "A series of 6- and 7-piperazinyl- and -piperidinylmethylbenzoxazinones with dopamine D4 antagonist activity: discovery of a potential atypical antipsychotic agent," Journal of Medicinal Chemistry, vol. 42, no. 25, pp. 5181-5187, 1999.

[28] J. P. Barnes and A. R. Putnam, "Role of benzoxazinones in allelopathy by rye (Secale cereale L.)," Journal of Chemical Ecology, vol. 13, no. 4, pp. 889-906, 1987.

[29] J. P. Barnes, A. R. Putnam, B. A. Burke, and A. J. Aasen, "Isolation and characterization of allelochemicals in rye herbage," Phytochemistry, vol. 26, no. 5, pp. 1385-1390, 1987.

[30] R. G. Belz and K. Hurle, "Differential exudation of two benzoxazinoids-one of the determining factors for seedling allelopathy of Triticeae species," Journal of Agricultural and Food Chemistry, vol. 53, no. 2, pp. 250-261, 2005.

[31] S. S. Krogh, S. J. M. Mensz, S. T. Nielsen, A. G. Mortensen, C. Christophersen, and I. S. Fomsgaard, "Fate of benzoxazinone allelochemicals in soil after incorporation of wheat and rye sprouts," Journal of Agricultural and Food Chemistry, vol. 54, no. 4, pp. 1064-1074, 2006.

[32] F. A. Macías, A. Oliveros-Bastidas, D. Marín, D. Castellano, A. M. Simonet, and J. M. G. Molinillo, "Degradation studies on benzoxazinoids: soil degradation dynamics of (2R)-2-O- $\beta$ D-glucopyranosyl-4-hydroxy-(2H)-1,4-benzoxazin-3(4H)-one (DIBOA-Glc) and its degradation products; phytotoxic allelochemicals from gramineae," Journal of Agricultural and Food Chemistry, vol. 53, no. 3, pp. 554-561, 2005.

[33] I. S. Fomsgaard, A. G. Mortensen, and S. C. K. Carlsen, "Microbial transformation products of benzoxazolinone and benzoxazinone allelochemicals-a review," Chemosphere, vol. 54, no. 8, pp. 1025-1038, 2004.

[34] N. R. Burgos, R. E. Talbert, and J. D. Mattice, "Cultivar and age differences in the production of allelochemicals by Secale cereale," Weed Science, vol. 47, no. 5, pp. 481-485, 1999.

[35] J. P. Yenish, A. D. Worsham, and W. S. Chilton, "Disappearance of DIBOA-glucoside, DIBOA, and BOA from rye (Secale cereale L.) cover crop residue," Weed Science, vol. 43, no. 1, pp. 18-20, 1995.

[36] N. G. Creamer, M. A. Bennett, B. R. Stinner, J. Cardina, and E. E. Regnier, "Mechanisms of weed suppression in cover cropbased production systems," HortScience, vol. 31, no. 3, pp. 410$413,1996$.

[37] J. R. Teasdale, C. P. Rice, G. Cai, and R. W. Mangum, "Expression of allelopathy in the soil environment: soil concentration and activity of benzoxazinoid compounds released by rye cover crop residue," Plant Ecology, vol. 213, no. 12, pp. 1893-1905, 2012.
[38] M. Schulz, A. Marocco, V. Tabaglio, F. A. Macias, and J. M. G. Molinillo, "Benzoxazinoids in rye allelopathy—from discovery to application in sustainable weed control and organic farming," Journal of Chemical Ecology, vol. 39, no. 2, pp. 154-174, 2013.

[39] E. C. Large, "Growth stages in cereals, illustrations of the Feekes scale," Plant Pathology, vol. 3, no. 4, pp. 128-129, 1954.

[40] M. M. Finney, D. A. Danehower, and J. D. Burton, "Gas chromatographic method for the analysis of allelopathic natural products in rye (Secale cereale L.)," Journal of Chromatography A, vol. 1066, no. 1-2, pp. 249-253, 2005.

[41] S. C. K. Carlsen, P. Kudsk, B. Laursen, S. K. Mathiassen, A. G. Mortensen, and I. S. Fomsgaard, "Allelochemicals in rye (Secale cereale L.): cultivar and tissue differences in the production of benzoxazinoids and phenolic acids," Natural Product Communications, vol. 4, no. 2, pp. 199-208, 2009.

[42] P. O. Lim, H. J. Kim, and H. G. Nam, "Leaf senescence," Annual Review of Plant Biology, vol. 58, pp. 115-136, 2007.

[43] B. B. Mogensen, T. Krongaard, S. K. Mathiassen, and P. Kudsk, "Quantification of benzoxazinone derivatives in wheat (Triticum aestivum) varieties grown under contrasting conditions in Denmark," Journal of Agricultural and Food Chemistry, vol. 54, no. 4, pp. 1023-1030, 2006.

[44] M. Kantar, C. Sheaffer, P. Porter, E. Krueger, and T. E. Ochsner, "Growth stage influences forage yield and quality of winter rye," Forage \& Grazinglands, vol. 9, no. 1, 2011.

[45] H. J. Ougham, P. Morris, and H. Thomas, “The colors of autumn leaves as symptoms of cellular recycling and defenses against environmental stresses," Current Topics in Developmental Biology, vol. 66, pp. 135-160, 2005.

[46] K. Kang, Y.-S. Kim, S. Park, and K. Back, "Senescence-induced serotonin biosynthesis and its role in delaying senescence in rice leaves," Plant Physiology, vol. 150, no. 3, pp. 1380-1393, 2009.

[47] P. L. Gregersen and P. B. Holm, "Transcriptome analysis of senescence in the flag leaf of wheat (Triticum aestivum L.)," Plant Biotechnology Journal, vol. 5, no. 1, pp. 192-206, 2007.

[48] J. L. De Bruin, P. M. Porter, and N. R. Jordan, "Use of a rye cover crop following corn in rotation with soybean in the upper Midwest," Agronomy Journal, vol. 97, no. 2, pp. 587-598, 2005.

[49] R. A. Mischler, W. S. Curran, S. W. Duiker, and J. A. Hyde, "Use of a rolled-rye cover crop for weed suppression in no-till soybeans," Weed Technology, vol. 24, no. 3, pp. 253-261, 2010.

[50] S. W. Duiker and W. S. Curran, "Rye cover crop for corn production in the northern Mid-Atlantic region," Agronomy Journal, vol. 97, no. 5, pp. 1413-1418, 2005.

[51] S. Hörtensteiner, "Stay-green regulates chlorophyll and chlorophyll-binding protein degradation during senescence," Trends in Plant Science, vol. 14, no. 3, pp. 155-162, 2009. 


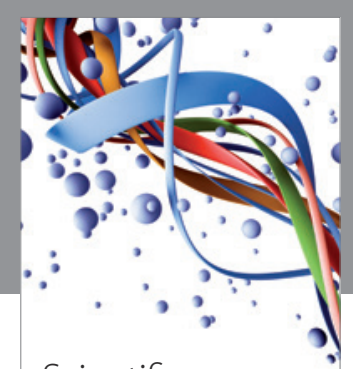

Scientifica
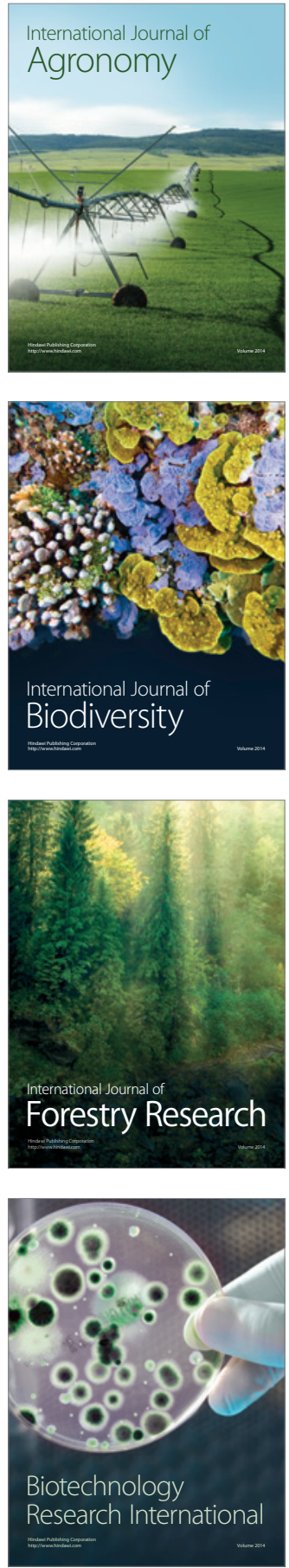
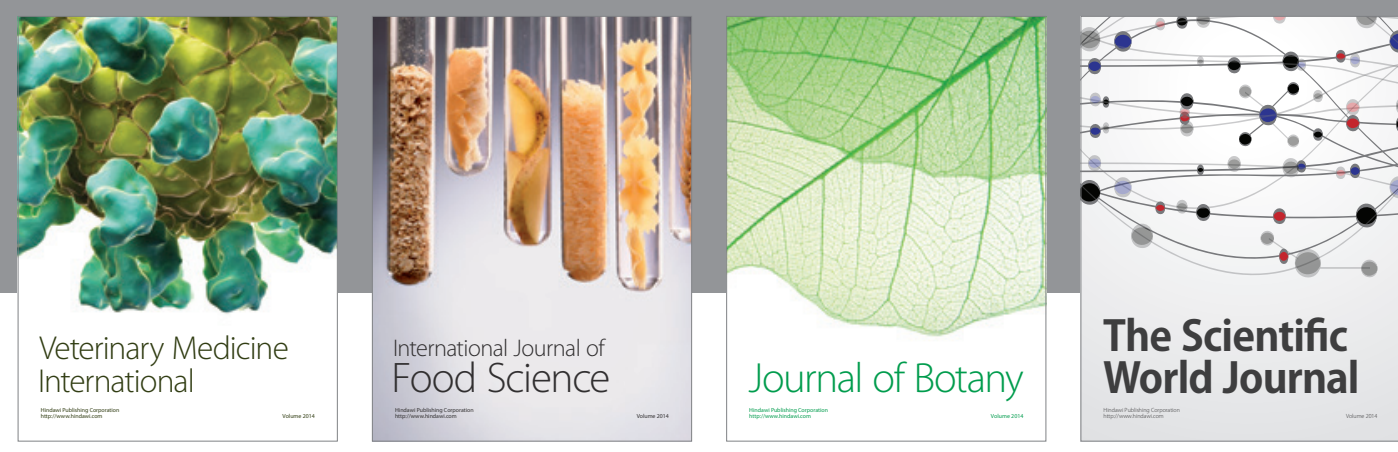

The Scientific

\section{World Journal}

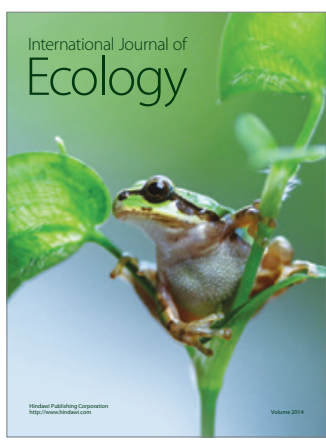

\section{Hindawi}

Submit your manuscripts at

http://www.hindawi.com
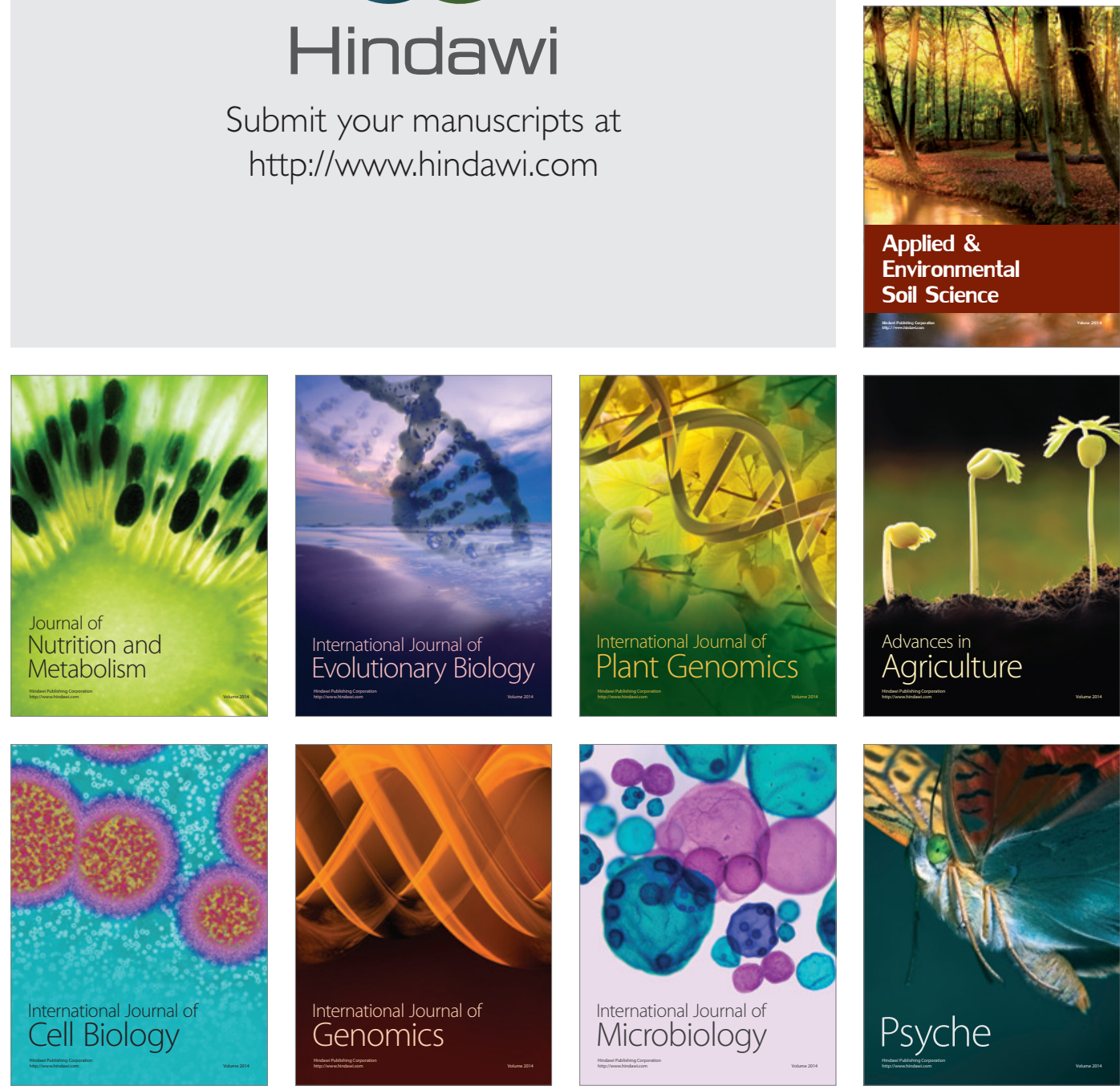
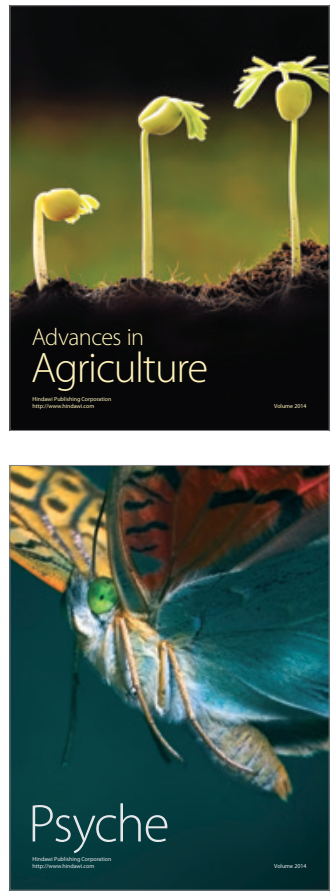